\title{
Fusarium ananatum sp. nov. in the Gibberella fujikuroi species complex from pineapples with fruit rot in South Africa
}

\author{
Adriaana Jacobs ${ }^{1}$, Pieter Schalk Van Wyk ${ }^{2}$, Walter F.O. Marasas ${ }^{3}$, Brenda D. Wingfield ${ }^{4}$, \\ Michael J. Wingfield ${ }^{1}$ and Teresa A. Coutinho ${ }^{1}$
}

(1) Department of Microbiology and Plant Pathology, Forestry and Agricultural Biotechnology Institute (FABI), University of Pretoria, Pretoria, South Africa

(2) Soygro, PO Box 457, Hartswater, South Africa

(3) Forestry and Agricultural Biotechnology Institute (FABI), University of Pretoria, Pretoria, South Africa

(4) Department of Genetics, Forestry and Agricultural Biotechnology Institute (FABI), University of Pretoria, Pretoria, South Africa

Adriaana Jacobs

Email: riana.jacobs@fabi.up.ac.za

\begin{abstract}
Pineapple (Ananas comosus) is native to South America and widely planted as a fruit crop in the tropics and sub-tropics. This plant is susceptible to a number of fungal diseases of which the most severe is fusariosis. The disease is caused by Fusarium guttiforme and occurs only in South and Central America. The occurrence of a similar disease on pineapples in South Africa has prompted a re-evaluation of the Fusarium sp. associated with pineapple fruit rot. Phylogenetic relationships of isolates from pineapples collected in Brazil and South Africa were assessed based on sequence data for the translation elongation factor- $1-\alpha$, histone $\mathrm{H} 3$ and $\beta$-tubulin gene regions. Analyses showed that the South African isolates represent a species distinct from Brazilian isolates. The South African isolates are characterised by a concentration of aerial mycelium at the centres of the colonies, different to the Brazilian isolates that have an even distribution of aerial mycelium. Both phylogenetic and morphological data show that the disease on pineapple in South Africa is caused by a new Fusarium species described here as F. ananatum sp. nov.
\end{abstract}

\section{Introduction}

Pineapple [Ananas comosus (L.) Merr.] is native to South America and is the fourth most important crop planted in the tropics (Ploetz 2001). The first report of a serious disease caused by a Fusarium species and known as fusariosis of pineapple was from Argentina in 1954 (Rohrbach 1994). Ten years later, this disease was reported from Brazil, where pineapple is an economically important crop. Pineapple fusariosis was so serious at that time that Brazil lost its position as the world's leading pineapple producer (Ploetz 2001; Ventura et al. 1993a).

All pineapple plant parts can be infected with the causal agent of fusariosis, but symptoms are most conspicuous on the fruit. Symptoms include bent or dead stem apices, shortened stems, disrupted phyllotaxy, general stunting and chlorosis (Pires de Matos 1995; Ploetz 2001). Fruit symptoms include an initial discolouration of the infected area exemplified by light to dark brown fruitlet septa, which may extend into the fruitlet core. The diseased areas become sunken and profuse pink fungal sporulation and gum exudation is evident (Pires de Matos, 1995; Rohrbach, 1994). Infection 
can occur from the start of flowering through all stages of fruit development. However, it is most severe when plants are infected during the early stages of flowering (Ploetz 2001).

Previously, the fungus causing fusariosis in pineapple was identified as $F$. subglutinans (Wollenw. \& Reinking) P.E. Nelson, Toussoun \& Marasas (basionym: F. moniliforme J. Sheld. var. subglutinans Wollenw. \& Reinking). The species is specific to pineapple, and causes fruitlet core rot and fusariosis (Ploetz 2001). Based on its host specificity, Ventura et al. (1993b) proposed a new forma specialis, F. subglutinans f. sp. ananas for the fungus. Nirenberg \& O'Donnell (1998) described this fungus as Fusarium guttiforme Nirenberg \& O'Donnell.

Fusarium guttiforme forms part of the G. fujikuroi complex. Species in this complex can be distinguished from each other based on morphological characteristics and DNA sequence comparisons (Nirenberg and O'Donnell 1998). The morphological characteristics used to distinguish between species in this group include conidiophore arrangement on the aerial mycelium, the number of conidiogenous openings on the polyphialides, the presence or absence of sterile coils or curved hyphae, and macroconidial morphology (Aoki et al. 2001; Nirenberg and O'Donnell 1998). DNA based characterisation most commonly considers sequence data for the ( $\beta$-tubulin, translation elongation factor- $1 \alpha$ and mitochondrial small subunit (mtSSU) genes (Aoki et al. 2001; O’Donnell et al. 1998).

Pineapple fusariosis has been reported only from South America (Ploetz 2001). In Cuba, a disease called "fusariose" caused by F. subglutinans has been reported (Borras et al. 2001; Hildalgo et al. 1999), but it is not clear whether it is the same disease as fusariosis in South America. A similar disease known as fruitlet core rot occurs in Hawaii (Rohrbach \& Pfeiffer 1976), and the associated 'F. moniliforme' strains have been incorrectly referred to as F. guttiforme (Nirenberg and O'Donnell 1998; Rohrbach and Schmitt 2003). Recently, a Fusarium species was isolated from pineapples with a fruit rot disease in South Africa and there was concern that this might reflect a first report of fusariosis in the country. Alternatively, the disease might have been the same as the one known as 'black spot' and associated with Penicillium funiculosum and ' $F$. moniliforme' in South Africa (Edmonstone-Sammons 1958). The aim of this study was to compare South African isolates from diseased pineapples with those from Brazil, including the ex-type isolate of $F$. guttiforme. Isolates were compared based on DNA sequences for the translation elongation factor- $1 \alpha$, the partial $\beta$ tubulin gene, and the histone $\mathrm{H} 3$ gene as well as on their morphology.

\section{Materials and Methods}

\section{Symptoms and isolations}

Diseased pineapple fruit were obtained from Hluhluwe, KwaZulu Natal. The symptoms on these fruit included an initial off-colour appearance, followed by the tissue becoming sunken with characteristic V-shaped lesions appearing on the outside of the fruit. This extends to the internal tissue and ultimately manifests itself as a core rot.

Primary isolations from the diseased material were done by placing small pieces $(3 \mathrm{~mm})$ of diseased tissue onto Fusarium selective medium (Nelson et al. 1983) in Petri dishes. These Petri dishes were incubated at $25{ }^{\circ} \mathrm{C}$ under cool-white fluorescent illumination. The plates were checked routinely and all the colonies with typical Fusarium morphology were transferred to half-strength potato dextrose agar (PDA) (Merck, Darmstadt, Germany). Single conidial cultures were stored using a cryopreservation method at $-70{ }^{\circ} \mathrm{C}$ in $15 \%$ glycerol aqueous solution. 


\section{Fungal isolates}

All isolates used in this study (Table 1) are maintained in the Fusarium culture collection of the Forestry and Agricultural Biotechnology Institute (FABI), University of Pretoria, Pretoria, South Africa, and in the Medical Research Council (MRC) Culture Collection, Tygerberg, Cape Town, South Africa. Representative isolates have also been deposited with the Centraalbureau voor Schimmelcultures (CBS), Utrecht, Netherlands.

\section{Morphological comparisons}

Isolates were grown on synthetic low nutrient agar (SNA) (Nirenberg 1976) and carnation leaf agar (CLA) (Nelson et al. 1983) for $7 \mathrm{~d}$ at $25^{\circ} \mathrm{C}$, under near ultraviolet light. Fungal structures produced on these media were mounted on microscope slides in lactophenol with cotton blue and used in the morphological comparison of the South African and Brazilian groups of isolates. Colony colour was assigned using the colour charts of Rayner (1970) for isolates grown on PDA $7 \mathrm{~d}$ at $25^{\circ} \mathrm{C}$, under near ultraviolet light. Growth rates were determined by placing a single macroconidium (Nelson et al. 1983) on a PDA plate and calculating the average growth in mm over $5 \mathrm{~d}$. The standard errors were determined for data representing each isolate at all temperatures. The presented measurements are the average of 50 measurements per morphological structure.

\section{DNA extraction and amplification}

Isolates were grown in complete medium (CM) (Correll et al. 1987) at $25^{\circ} \mathrm{C}$ for $7 \mathrm{~d}$. DNA was isolated using a modified version of the technique described by Raeder \& Broda (1985). Mycelium was placed in Eppendorf tubes and ground with ca. $10 \mu \mathrm{g}$ sterile, chemically treated sand in $500 \mu \mathrm{L}$ of DNA extraction buffer [DEB: $200 \mathrm{mM}$ Tris- $\mathrm{HCl} \mathrm{pH}$ 8, $150 \mathrm{mM} \mathrm{NaCl}, 25 \mathrm{mM}$ EDTA, $0.59 \%$ SDS]. Thereafter, $500 \mu \mathrm{L}$ of phenol and $300 \mu \mathrm{L}$ chloroform were added, mixed and centrifuged for $30 \mathrm{~min}$ at $10000 \mathrm{rpm}$. The phenol/chloroform step was repeated until the interface was clean. The supernatant was transferred to a new tube and double the volume of $100 \%$ ethanol was added and mixed. The DNA was allowed to precipitate at $4{ }^{\circ} \mathrm{C}$ overnight and then pelleted by centrifugation for $30 \mathrm{~min}$ at $11000 \mathrm{rpm}$. Pellets were washed with $300 \mu \mathrm{l} 70 \%$ ethanol, dried and resuspended in $50 \mu \mathrm{L}$ sterile distilled water and $3 \mu \mathrm{L}$ RNase $(2.5 \mu \mathrm{M})$ (Roche Pharmaceuticals, Basel, Switzerland).

Extracted DNA was used as template in PCR reactions to amplify regions of the histone $\mathrm{H} 3, \beta$ tubulin (BT) and translation elongation factor- $1 \alpha$ (TEF) genes. The histone $\mathrm{H} 3$ gene region was amplified using primer sets H3-1a (5'-ACTAAGCAGACCGCCCGCAG-3') and H3-1b (5'GCGGGCGAGCTGGATGTCCTT-3') (Glass \& Donaldson 1995). Part of the TEF was amplified using the primer set EF1 (5'-CGAATCTTTGAACGCACATTG-3') and EF2 (5'CCGTGTTTCAAGACGGG-3') (Carbone \& Kohn 1999). The BT gene region was amplified using the primer set T1 (5'-AACATGCGTGAGATTGTAAGT-3') and T222 (5'-

GACCGGGGAAACGGAGACAGG-3') (O'Donnell et al. 2000). The PCR reaction consisted of 1× Roche Taq reaction buffer with $\mathrm{MgCl}_{2}$, dNTPs $(250 \mu \mathrm{M}$ each), primers $(0.2 \mu \mathrm{M}$ each), template DNA (25 ng) and Roche Taq polymerase (0.5 U) (Roche Pharmaceuticals). The PCR reaction conditions, for the amplification of the histone $\mathrm{H} 3$ gene, were an initial denaturation at $92{ }^{\circ} \mathrm{C}$ for 1 min. This was followed by 30 cycles of denaturing at $92{ }^{\circ} \mathrm{C}$ for $1 \mathrm{~min}$, annealing at $63{ }^{\circ} \mathrm{C}$ for $1 \mathrm{~min}$ and elongation at $72{ }^{\circ} \mathrm{C}$ for $1 \mathrm{~min}$, followed by a final elongation step at $72{ }^{\circ} \mathrm{C}$ for $5 \mathrm{~min}$. The TEF and BT gene regions were amplified by initial denaturation at $94{ }^{\circ} \mathrm{C}$ for $2 \mathrm{~min}$. This was followed by 30 cycles of denaturation at $94{ }^{\circ} \mathrm{C}$ for $1 \mathrm{~min}$, annealing at $54{ }^{\circ} \mathrm{C}$ for $1 \mathrm{~min}$ and elongation at 72 ${ }^{\circ} \mathrm{C}$ for $1 \mathrm{~min}$, with a final elongation step at $72{ }^{\circ} \mathrm{C}$ for $5 \mathrm{~min}$. The resulting PCR amplicons were purified using a QIAquick PCR Purification kit (QIAGEN, Hilden, Germany). 
Table 1. List of the Fusarium strains included in the phylogenetic analyses, representing closely related species in the Gibberella fujikuroi species complex.

\begin{tabular}{|c|c|c|c|c|c|c|c|c|}
\hline \multirow[t]{2}{*}{ Strain number' } & \multirow[t]{2}{*}{ Species } & \multirow{2}{*}{$\begin{array}{l}\text { Original } \\
\text { identification }\end{array}$} & \multirow[t]{2}{*}{ Origin } & \multirow[t]{2}{*}{ Collecter } & \multicolumn{3}{|c|}{ Geniank accession number } & \multirow{2}{*}{$\begin{array}{l}\text { Reference for } \\
\text { DNA sequences }\end{array}$} \\
\hline & & & & & B- tubutin & Eengation factor 1- $\alpha$ & Histone H3 & \\
\hline $\begin{array}{l}\text { MaC C8165/7CC 2986,CNAW } \\
\text { 18685,Css 118516, } \propto-t y p e\end{array}$ & F. ananutem & Fuastiem ap. & $\begin{array}{l}\text { Arumsa comosic, } \\
\text { Socath Afriea }\end{array}$ & ns wa wyk & DC282174 & DQ282567 & DCosans1 & This atudy \\
\hline 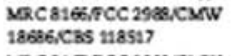 & F. ananatien & Feastiem sp. & $\begin{array}{l}\text { Anamas comosic, } \\
\text { South Africa }\end{array}$ & ps vas wyk & DQ282178 & $D Q 202121$ & DQ2an182 & This study \\
\hline $\begin{array}{l}\text { MaCB1E/FCC } 2990 \text { CMNW } \\
18687 \text { CBS } 118518\end{array}$ & F. axaration & Pvastion ap. & $\begin{array}{l}\text { Anamas comos is, } \\
\text { South Afria }\end{array}$ & rs vas wyk & DC28n76 & DCQS2569 & De28n83 & Thesaty \\
\hline $\begin{array}{l}\text { MaC B168,7CC 2994CMNW } \\
\text { 18688,CBS 118519 }\end{array}$ & F. ananutam & Feastum ap. & $\begin{array}{l}\text { Anamas comcesic, } \\
\text { South Afrisa }\end{array}$ & rs wa wyk & Depani75 & DCes2ss8 & DC282180 & Thต sะaดy \\
\hline$F \propto C 4251 / C M N W 28597$ & F. ananatam & Fuastion ap. & $\begin{array}{l}\text { Anamas comocila, } \\
\text { Socath Africa }\end{array}$ & A /20000s & zu668300 & घN668312 & & Thissaby \\
\hline$F \subset C 4252, C M N W 22898$ & F. amonatum & Feastien sp. & $\begin{array}{l}\text { Aramsiamecis, } \\
\text { South Africa }\end{array}$ & A jacoba & EU66830 & EN668313 & & Thus andy \\
\hline$F \subset C 4233, C N \times W 28599$ & F. ananutan & Fuasticm sp. & $\begin{array}{l}\text { Anamas comosis, } \\
\text { Socth Africa }\end{array}$ & A jacoba & Eu66a311 & EN668314 & & Thus atudy \\
\hline Nasch 23900 , extype & E. toypriae & & $\begin{array}{l}\text { Beyoula tyborid, } \\
\text { Gemnary }\end{array}$ & Unkerasa & Ar329045 & AY329036 & & O'Donaell e at. ass \\
\hline Noxh. 19618, extype & F. bubioda & & $\begin{array}{l}\text { Nerike boudenli, } \\
\text { Germany }\end{array}$ & Unḱmoss & U61546 & NF160254 & & O'Doneell c a al. 898 \\
\hline NR:3h. 25331, extype & E. dicinutum & & $\begin{array}{l}\text { Nina natinsa, } \\
\text { USA }\end{array}$ & Unkenowa & U61547 & NF1602\% & AFISOE 2 & $\begin{array}{l}\text { ODDonell \& at. } 1996 \\
\text { Steerkamp \& al. } 1999\end{array}$ \\
\hline Mac6213/2SSU 10 so 0 & 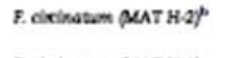 & & $\begin{array}{l}\text { Pinda sp, } \\
\text { South Africa }\end{array}$ & A vilyen & & & AFis0644 & Steerkampes al. $19 n 9$ \\
\hline Mac7483xsu 10647 & E. oirinatem (xenT H.4) & & South Africa & A vilicen & & & AF23848 & Steervikamp \& al. 1999 \\
\hline 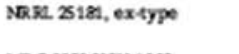 & E. conowaricem & & $\begin{array}{l}\text { Wusa appientem, } \\
\text { Coata riea }\end{array}$ & Unk̇áoma & AF333951 & NF333935 & & ODonellíc at. v9s \\
\hline sac65Xaxsu 1993 & 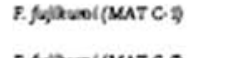 & & $\begin{array}{l}\text { Orgas sustua, } \\
\text { Takas }\end{array}$ & Fleste & & & AF 15093 & Steerkamp es al. 1989 \\
\hline sac6571xssu 1995 & 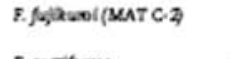 & & $\begin{array}{l}\text { Oryza sastua, } \\
\text { Taiman }\end{array}$ & Fitedse & & & AFts062 2 & Steerkamp e al. 1909 \\
\hline $\begin{array}{l}\mathrm{MaC} 672, \mathrm{CMNW} \\
30032 / \mathrm{CBS} 24346\end{array}$ & E. guagome & 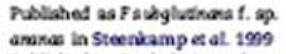 & $\begin{array}{l}\text { Anamas comocis, } \\
\text { Brazl }\end{array}$ & in Venzas & DQ2ann & $D Q 082100$ & AF 150804 & Thusady \\
\hline $\begin{array}{l}\text { MaC 6783,CMNW } \\
30033, \mathrm{CBS} 224445\end{array}$ & F. guasome & 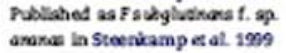 & $\begin{array}{l}\text { Aramis comocis, } \\
\text { Brazll }\end{array}$ & IM Ventas & Depsan73 & DCQ282566 & AF 150633 & ThLs szady \\
\hline Mac 753, extype & F. guasome & & $\begin{array}{l}\text { Anamas comoses, } \\
\text { Brazll }\end{array}$ & H Nireaberg & $D C 282172$ & Does2965 & Dops2179 & This atady \\
\hline Nax. 29945 & F. $g: 0,6 \mathrm{mme}$ & 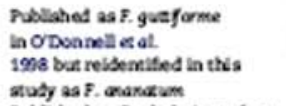 & $\begin{array}{l}\text { Axamas cumoers, } \\
\text { Eneland }\end{array}$ & Unùaora & 034420 & AF1602S & & ODonaell $<$ at. 2898 \\
\hline $\operatorname{sac} 678$ & F. $g$ usfome & 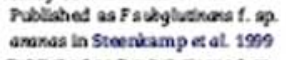 & $\begin{array}{l}\text { Aramia comosica, } \\
\text { Brazall }\end{array}$ & in Venas & & & AFISCes6 & Steerkamp e al. 1909 \\
\hline Mac eas & F.guajorme & 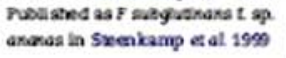 & $\begin{array}{l}\text { Amonas mmerca } \\
\text { Breal }\end{array}$ & IA vertura & & & AP150835 & Sxenkampetat 199 \\
\hline $\operatorname{sac} 7559$ & F. manglene & & $\begin{array}{l}\text { Manglfora india, } \\
\text { Sount Atrica }\end{array}$ & Unknewa & & & An23879 & Sxenkamp e al 1990 \\
\hline $\operatorname{sac} 347$ & F. manglerae & & $\begin{array}{l}\text { Nonglfora indio, } \\
\text { Souh Atrica }\end{array}$ & Uaknewa & & & APL50868 & Sxenkamp \& at 1990 \\
\hline Nose. 19488, ex-ype & F.nygamal & & $\begin{array}{l}\text { Songhum Bindor, } \\
\text { Australia }\end{array}$ & Unkawewa & U34481 & AFPSO2Z3 & & ODoniell e \&. 1998 \\
\hline $\operatorname{sac} 75487 \times 5 U 5111$ & F. nygamal (NeTT G-4) & & Lab csoas & F Leilo & & & APISCES4 & Sxenkamp e al 199 \\
\hline Mac 75497xsu 5412 & F. nygumal (NAT C2) & & $\begin{array}{l}\text { lab cosas } \\
\text { souph Atica }\end{array}$ & $\begin{array}{l}\text { TP Lello } \\
\text { A Vatioea }\end{array}$ & & & 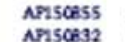 & $\begin{array}{l}\text { Sxenkamp ef al } 1990 \\
\text { Seenkamp of al } 199\end{array}$ \\
\hline $\begin{array}{l}\text { MaC } 212 \\
\text { Nost. } 26374\end{array}$ & 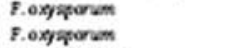 & & $\begin{array}{l}\text { Souh Atrica } \\
\text { Unkenowa }\end{array}$ & $\begin{array}{l}\text { A Vajoea } \\
\text { Uakawewa }\end{array}$ & AFCCAS 28 & Aroces43 & Anf 150032 & $\begin{array}{l}\text { Seenkamp es al } 1998 \\
\text { ODanielles } \alpha \text {. } 1998\end{array}$ \\
\hline Nose. 22044 & F.prolyeratem & & $\begin{array}{l}\text { Castlya tyborh, } \\
\text { Cermany }\end{array}$ & Uaknewa & U 3447 & AF $560: 80$ & & ODAnmell $\angle$ \& 1998 \\
\hline No3e. 39071 & F.proilferatum & & Unúawe & Unkawea & & & A229059 & Stenkamp e d. 1998 \\
\hline 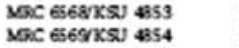 & 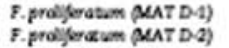 & & $\begin{array}{l}\text { Lab coas } \\
\text { Lab ross }\end{array}$ & $\begin{array}{l}\text { TP Lelle } \\
\text { F Leste }\end{array}$ & & & $\begin{array}{l}\text { An150e71 } \\
\text { API50870 }\end{array}$ & $\begin{array}{l}\text { Seenkamp es \&. } 1990 \\
\text { Seenkamp es Q. } 1999\end{array}$ \\
\hline Nose. 22946 ex-9ype & E. pacadorindinatiom & & $\begin{array}{l}\text { Solanum sp. } \\
\text { Casia }\end{array}$ & Unkays & U344 2 & AFSEO2D1 & Aph 50870 & $\begin{array}{l}\text { Seenkamp e d. } 1990 \\
\text { ODannellie \&. } 1998\end{array}$ \\
\hline 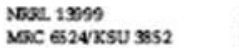 & 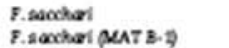 & & $\begin{array}{l}\text { Unkenowa } \\
\text { Lab cxas }\end{array}$ & $\begin{array}{l}\text { Unkwowa } \\
\text { g Lesle }\end{array}$ & U344es & AF 560278 & Ansce61 & $\begin{array}{l}\text { ODoncell es d. } 1998 \\
\text { Sxenkampet al } 1990\end{array}$ \\
\hline MaC es251Xsu 7853 & F.sachari (xeAT 3.2) & & tab cxas & IF Leste & & & NPISCE 60 & Sxenkamp es at 1990 \\
\hline $\operatorname{sac} 7273$ & F.aselikyphowem & & $\begin{array}{l}\text { Nang/fra india, } \\
\text { South Atrica }\end{array}$ & Uaknewa & & & $A P 23874$ & Srenkampe at 1990 \\
\hline $\sec \times 05$ & F. aseriayphocen & & $\begin{array}{l}\text { Nongifro india, } \\
\text { Souh Atrica }\end{array}$ & Unkwowa & & & $A P 23873$ & Sxenkamp \& at 1990 \\
\hline $\operatorname{sac} 6127 \times s u 2192$ & 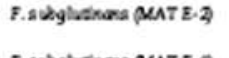 & & Zas maya USA & If Lelle & AF3e6552 & NF560289 & NRISCe 44 & $\begin{array}{l}\text { ODonielle A. 1998; } \\
\text { Sxenkamp at at 1990 }\end{array}$ \\
\hline $\operatorname{sac} 64837 x s u$ 90 & 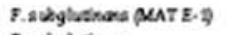 & & Za maya, USA & TF Lesto & & & NFISCOA5 & Sxenkamp e at 1990 \\
\hline $\operatorname{sac} x$ & F.sulytutikas & & $\begin{array}{l}\text { Znumaya } \\
\text { South Atrica }\end{array}$ & FCWehrer & & & APssces? & Sxenkamp e al 1980 \\
\hline 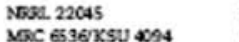 & 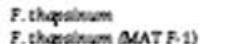 & & $\begin{array}{l}\text { Unuanowa } \\
\text { labcosas }\end{array}$ & $\begin{array}{l}\text { Unkawera } \\
\text { F Letere }\end{array}$ & U34473 & AFPEOD20 & & ODaniell e d. 1998 \\
\hline 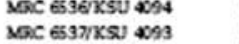 & 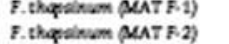 & & $\begin{array}{l}\text { Lab cosas } \\
\text { Lab cross }\end{array}$ & $\begin{array}{l}\text { F Leive } \\
\text { F Leslo }\end{array}$ & & & 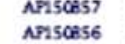 & \\
\hline Nool 22172 & F. vertollibisa & & Unḱanewa & Unkasea & U34468 & AFs60362 & & ODanellies $\alpha .1998$ \\
\hline $\operatorname{sac} 6155 \times$ KSIJ 449 & F. vertolibisan (MAT A4) & & $\begin{array}{l}\text { Soryhum } \\
\text { Biolor, USA }\end{array}$ & F Leste & & & APLSCESB & Steenkamp \& \&. 1990 \\
\hline 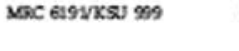 & 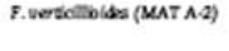 & & $\begin{array}{l}\text { Zas maya } \\
\text { usa }\end{array}$ & If Lesto & & & AfIScess & Treenkamp \& \&. 1990 \\
\hline
\end{tabular}

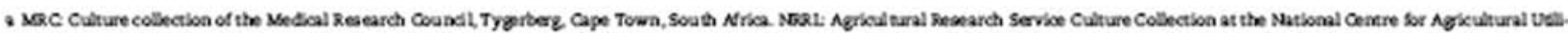

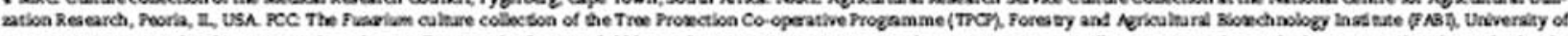

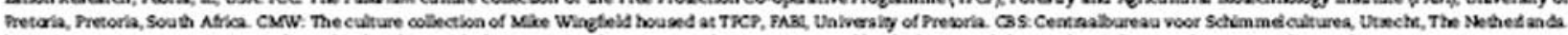

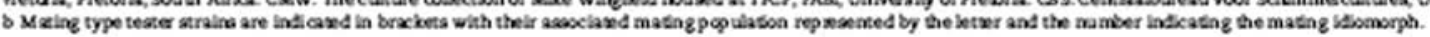

\section{DNA sequencing and phylogenetic analyses}

DNA sequences were determined from PCR amplicons using the ABI PRISMTM Dye Terminator Cycle Sequencing Ready Reaction Kit with AmpliTaq ${ }^{\circledR}$ DNA Polymerase, (Applied Biosystems, 
Warrington, UK) using the primers H3-1a, H3-1b, EF1, EF2, T1, and T222. Sequences generated in this study have been deposited in GenBank (Table 1).

DNA sequences were manually aligned by inserting gaps. Gaps were treated as new state in the subsequent analysis. Phylogenetic analysis was based on parsimony using PAUP 4.0* (Phylogenetic Analysis Using Parsimony* and Other Methods version 4; Swofford 2002). Heuristic searches were done with random addition of sequences (100 replicates), tree bisection-reconnection (TBR) branch swapping, and MULPAR effective and MaxTrees set to auto-increase. Phylogenetic signal in the data sets (g1) was assessed by evaluating tree length distributions over 100 randomly generated trees (Hillis \& Huelsenbeck 1992). The consistency (CI) and retention (RI) indices were determined for all data sets. Phylogenetic trees were rooted with F. oxysporum as monophyletic sister outgroup to the rest of the taxa. Bootstrap analyses were performed to determine branching point confidence intervals (1000 replicates) for the most parsimonious trees generated for the TEF, BT and histone $\mathrm{H} 3$ data sets. The combinability of the TEF and BT data sets was tested using the partition homogeneity test in PAUP 4.0* (Farris et al. 1994).

Bayesian analyses utilized the Metropolis-coupled Markov Chain Monte Carlo search algorithm as implemented in the program MrBayes 3.0b4 (Huelsenbeck \& Ronquist 2001). All Bayesian analyses consisted of 1000000 generations running one cold and three heated chains, with Bayesian inference posterior probabilities (biPP) calculated after a burnin was determined. BInt analyses utilized the GTR + I substitution model with separate parameters for each gene (partition) and an eight-category gamma model. The data sets were deposited in Treebase SN 4077.

\section{Mating studies and MAT genes}

In order to determine the mating types of the seven isolates from pineapple in South Africa, the MAT-1 and MAT-2 loci were amplified using PCR, as described by Steenkamp et al. (2000). The MAT idiomorphs were amplified with the primer sets GFmatla (5'-

GTTCATCAAAGGGCAAGCG-3'), GFmat1b (5'-TAAGCGCCTC-TTAACGCCTTC-3'), GFmat2c (5'-AGCGTCATT-ATTCG-ATCAAG-3') and GFmat2d (5'-

CTACGTTGAGAGCTGTACAG-3') (Steenkamp et al. 2000). The following PCR reaction mixture was used: $1 \times$ PCR buffer with $\mathrm{MgCl}_{2}$, dNTP $(250 \mu \mathrm{M})$ each, primers $(0.1 \mu \mathrm{M}$ of each), template DNA (25 ng) and $0.5 \mathrm{U}$ Roche Taq polymerase (Roche Pharmaceuticals). The PCR reaction conditions were an initial denaturation at $92{ }^{\circ} \mathrm{C}$ for $1 \mathrm{~min}$, followed by 35 cycles of denaturation at $92{ }^{\circ} \mathrm{C}$ for $30 \mathrm{~s}$, annealing at $63{ }^{\circ} \mathrm{C}$ for $30 \mathrm{~s}$ and elongation at $72{ }^{\circ} \mathrm{C}$ for $30 \mathrm{~s}$. A final elongation step was done at $72{ }^{\circ} \mathrm{C}$ for $5 \mathrm{~min}$. The products were resolved on a $1 \%$ agarose gel, containing ethidium bromide $(0.2 \mu \mathrm{g} / \mathrm{ml})$ and visualised under UV light. The presence of the MAT idiomorphs in the pineapple isolates was confirmed by amplification of the MAT loci.

\section{Results}

\section{Symptoms and isolations}

The external fruit symptoms on South African pineapples (Fig 1) were similar to but less severe than those reported for F. guttiforme infections on pineapples (Ploetz 2001; Rohrbach 1994). Isolations from these symptoms yielded cultures that resembled F. guttiforme. Seven of these isolates were used in this study. 


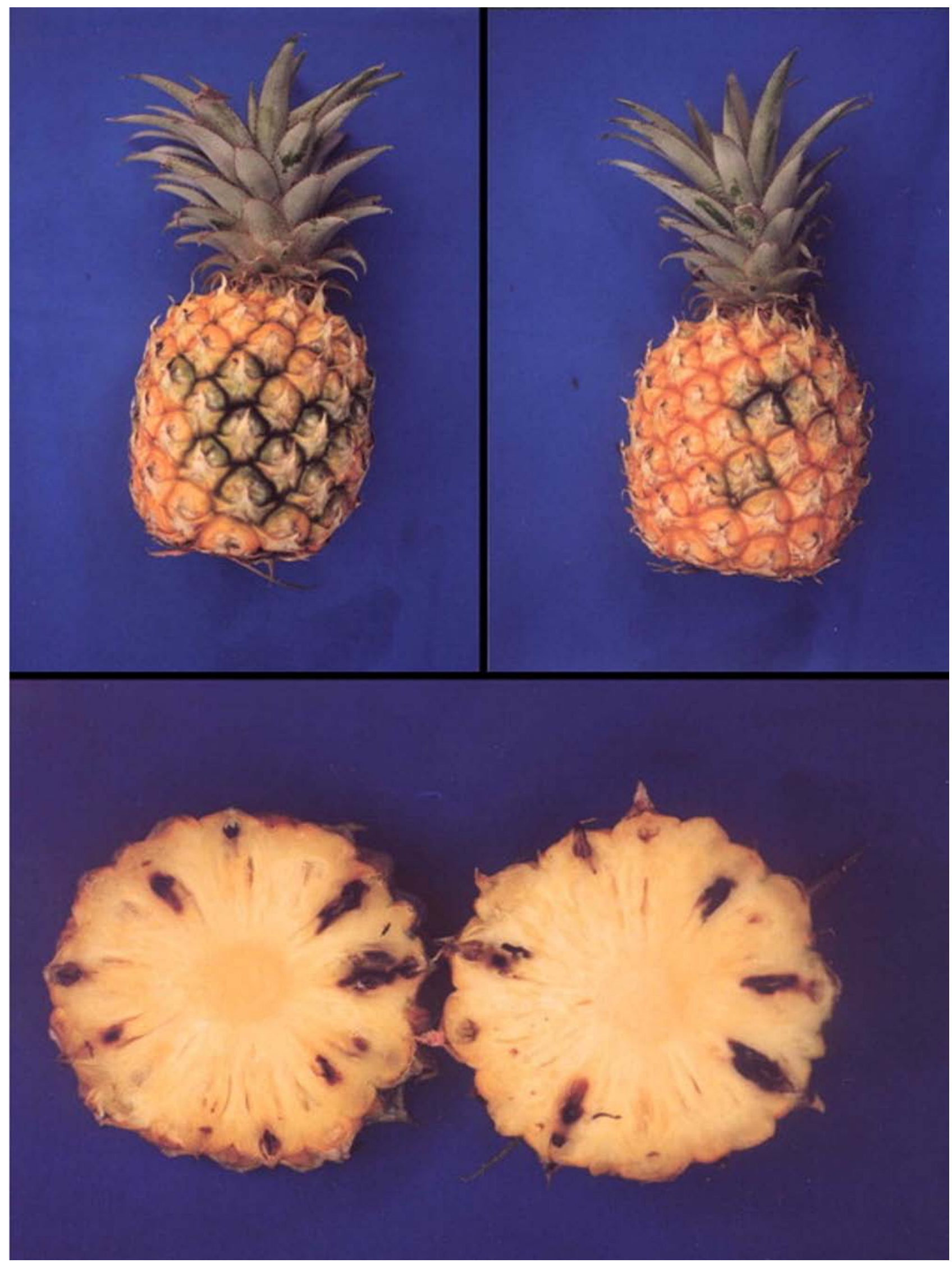

Fig 1. Internal and external lesions formed on susceptible pineapple fruits. 


\section{Morphological comparisons}

\section{Sequence comparisons and phylogenetic analyses on the TEF, BT and histone $\mathrm{H3}$ genes}

The amplification of the TEF, BT and histone H3 gene regions resulted in products of 640,520 and $540 \mathrm{bp}$, respectively.

Parsimony analysis of combined and separate data sets for the TEF and BT gene regions were done to determine the phylogenetic placement of F. guttiforme isolates from Brazil in relation to the South Africa pineapple isolates in the Gibberella fujikuroi species complex. The partition homogeneity test showed sufficient probability to accept the null hypothesis $(\mathrm{P}<0.5)$ to combine the data sets for the TEF and BT gene regions. Alignment of combined data by inserting gaps resulted in a total of 1059 characters used in the comparison of the different species in the combined data sets. All parsimony-uninformative and constant characters were excluded, resulting in 127 parsimony-informative characters. Heuristic searches on the data set generated one most parsimonious tree (Fig 2). Alignment of separate TEF data set by inserting gaps resulted in a total of 528 characters used in the comparison of the different species. All parsimony-uninformative and constant characters were excluded, resulting in 53 parsimony-informative characters. Heuristic searches on the data set generated six most parsimonious trees (Fig 3). The separate BT data set consisted of 484 parsimony-uninformative and 46 parsimony-informative characters. Heuristic searches on the data set generated two most parsimonious trees (Fig 4).

In the combined data set, the Brazilian isolates from pineapple, grouped together with the ex-type isolate of $F$. guttiforme to form a distinct clade (Fig 2). The South African isolates from diseased pineapple formed a separate clade, with $99 \%$ bootstrap support. The grouping of all Fusarium isolates associated with pineapples from both Brazil and South Africa was supported by a bootstrap value of $96 \%$. Some differences were found in the sequences of the South African pineapple isolates, most likely indicating genetic variation in this population.

In the separate TEF data set (Fig 3), the Brazilian isolates from pineapple grouped together with the ex-type isolate of $F$. guttiforme to form a distinct clade, although not supported by a high bootstrap value. The South African isolates from diseased pineapple formed a separate clade, with $87 \%$ bootstrap support. Some differences were found in the sequences of the South African pineapple isolates, most likely indicating genetic variation in this population. In the separate BT data set the Brazilian isolates from pineapple, grouped together with the ex-type isolate of $F$. guttiforme to form a distinct clade (Fig 4). The South African isolates from diseased pineapple formed a separate clade with $95 \%$ bootstrap support.

Parsimony analysis on the histone $\mathrm{H} 3$ gene region was done separately to those of the other gene regions because data from representatives of the different mating populations of G. fujikuroi were included to test the grouping of four South African and Brazilian isolates from pineapple. All parsimony-uninformative and constant characters were excluded, resulting in 85 parsimonyinformative characters. Heuristic searches on the data set generated one most parsimonious tree after reweighing of the characters based on the CI value (Fig 5). The topography of the tree was similar to that obtained for combined sequences of the TEF and BT gene regions. The Brazilian isolates grouped together with the ex-type culture of F. guttiforme (MRC 7539) and they represent a discrete taxon. The South African isolates from diseased pineapple resided in a distinct clade supported by a bootstrap value of $88 \%$. 


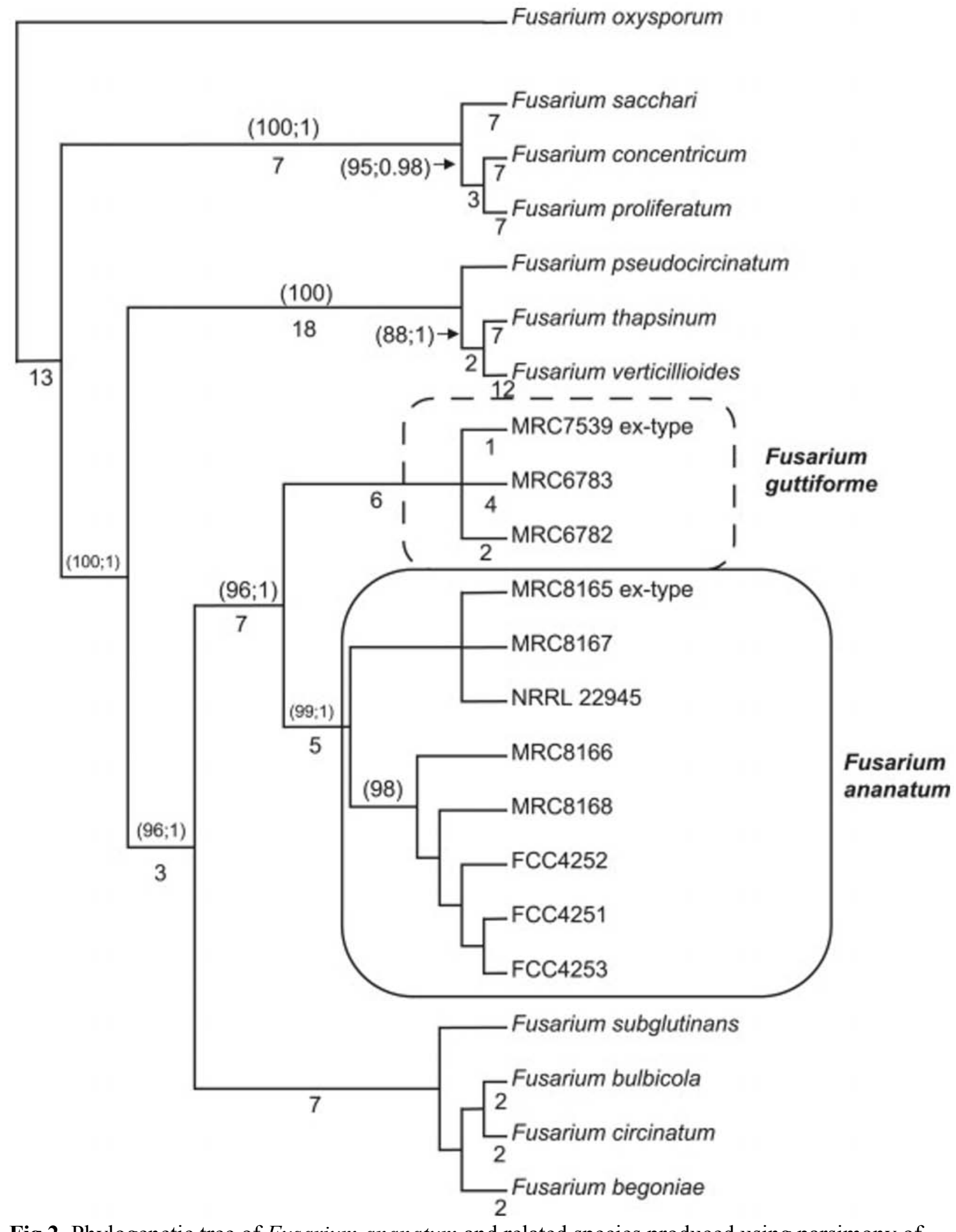

Fig 2. Phylogenetic tree of Fusarium ananatum and related species produced using parsimony of the combined data of the translation elongation factor- $1 \alpha$ and $\beta$-tubulin genes, with $F$. oxysporum as outgroup. Bootstrap values above $50 \%$ (percentages of 1000 bootstrap replicates) and the Bayesian posterior probability values are indicated in brackets above the branches of the tree. Branch lengths are indicated below the branches. Parsimony-informative characters $=127 ; \mathrm{CI}=0.8593 ; \mathrm{RI}=$ $0.9395 ; \mathrm{g} 1=-0.860858$. 


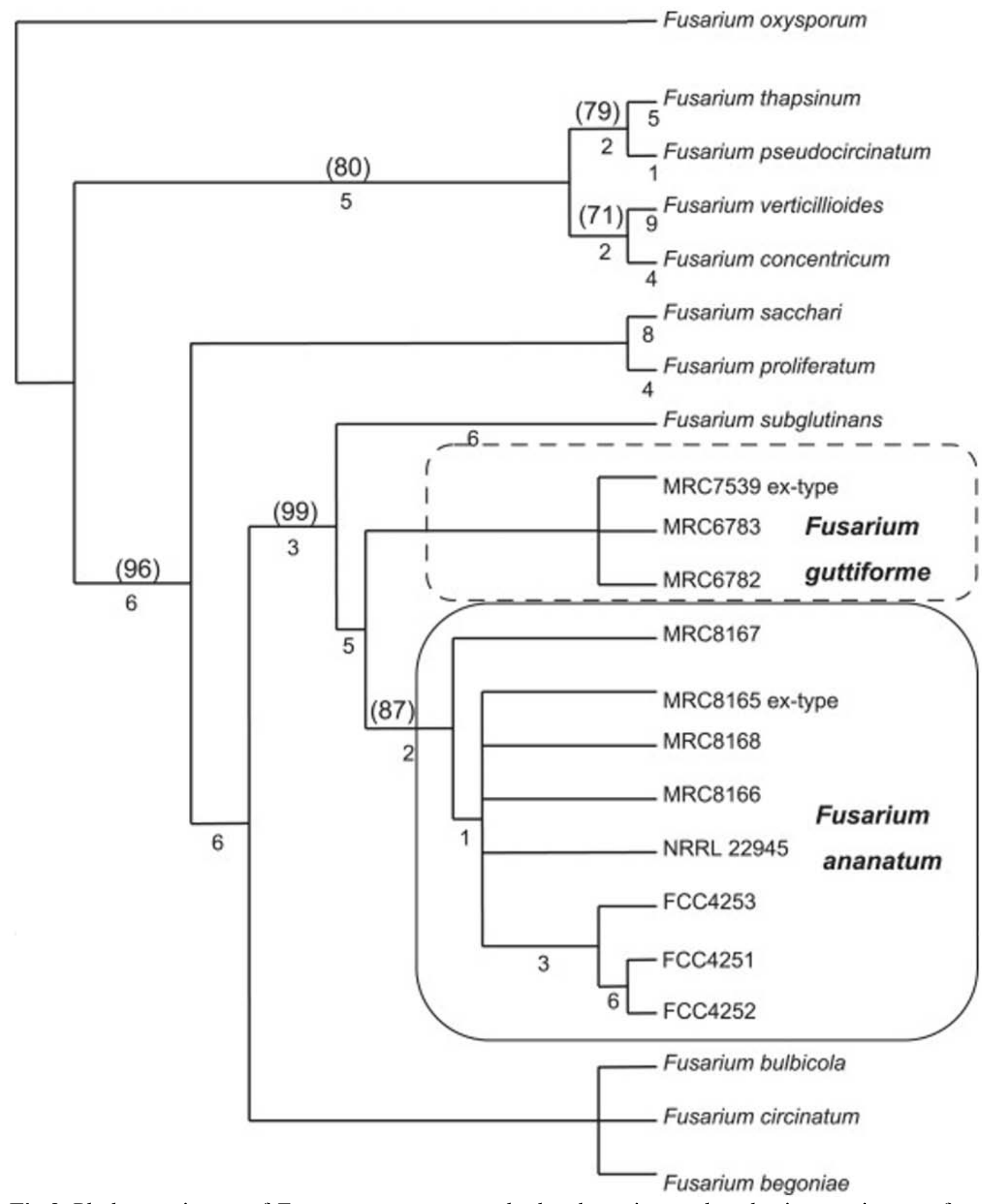

Fig 3. Phylogenetic tree of Fusarium ananatum and related species produced using parsimony of the translation elongation factor- $1 \alpha$ gene with $F$. oxysporum as outgroup. Bootstrap values above 50 $\%$ (percentages of 1000 bootstrap replicates) are indicated in brackets above the branches of the tree. Branch lengths are indicated below the branches. Parsimony-informative characters $=53 ; \mathrm{CI}=$ $0.6737 ; \mathrm{RI}=0.8510 ; \mathrm{g} 1=-0.476216$. 


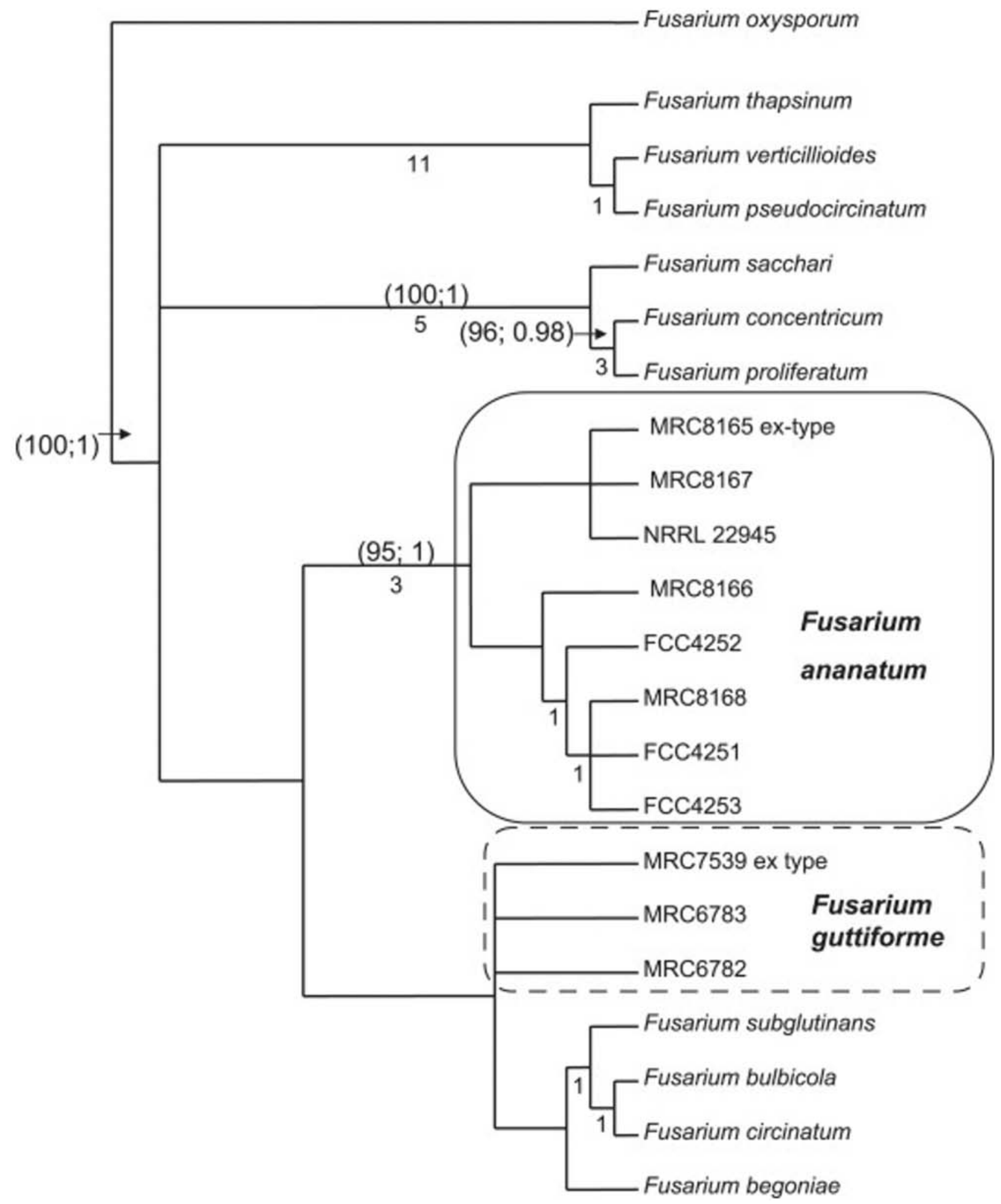

Fig 4. Phylogenetic tree of Fusarium ananatum and related species produced using parsimony of the $\beta$-tubulin gene region with $F$. oxysporum as outgroup. Bootstrap values above $50 \%$ (percentages of 1000 bootstrap replicates) and the Bayesian posterior probability values are indicated in brackets above the branches of the tree. Branch lengths are indicated below the branches. Parsimonyinformative characters $=46 ; \mathrm{CI}=0.8593 ; \mathrm{RI}=0.9395 ; \mathrm{g} 1=-0.860858$. 


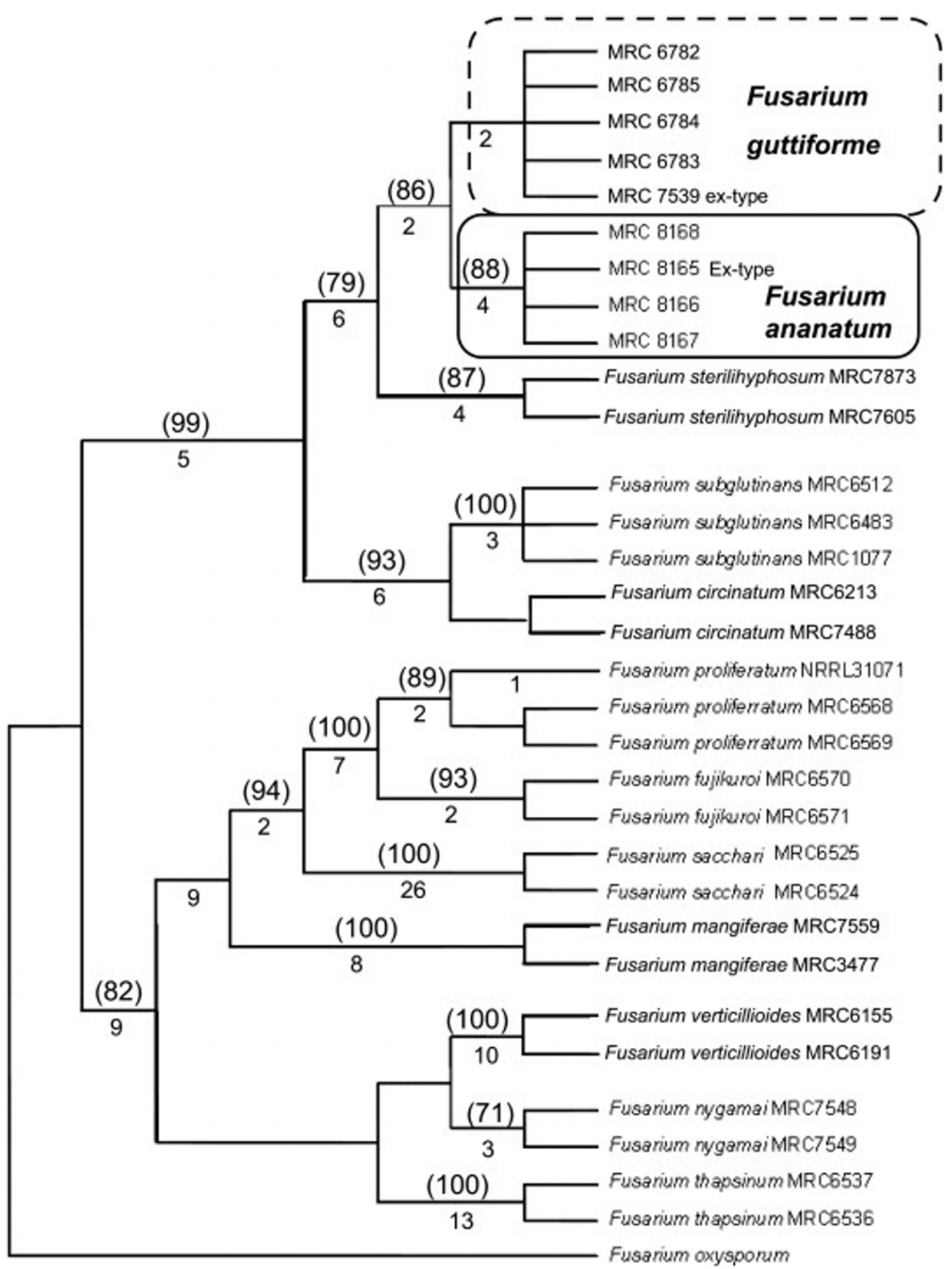

Fig 5. Phylogenetic tree of Fusarium ananatum and related species produced using parsimony of the histone $\mathrm{H} 3$ gene with $F$. oxysporum as outgroup. Bootstrap values above $50 \%$ (percentages of 1000 bootstrap replicates) are indicated in brackets above the branches of the tree. Branch lengths are indicated below the branches. Parsimony-informative characters $=53 ; \mathrm{CI}=0.6737 ; \mathrm{RI}=$ 0.8510 ; $\mathrm{g} 1=-0.476216$. 
Based on the results of the phylogenetic analyses, careful morphological comparisons were done. The South African isolates with the ex-type of F. guttiforme as well as other Brazilian isolates of the species showed that they could be distinguished based on a number of morphological characteristics. The Brazilian isolates were characterised by dark purple colonies on PDA but with dispersed aerial mycelium and where the conidiophores produced in these hyphae are prostrate. The South African isolates were characterised by saffron-coloured colonies on PDA (Fig 6). In older cultures, a dark purple colour appeared at the colony centres in the South African isolates.

Furthermore, the aerial mycelium of these isolates was concentrated at the middle of the SNA plates.

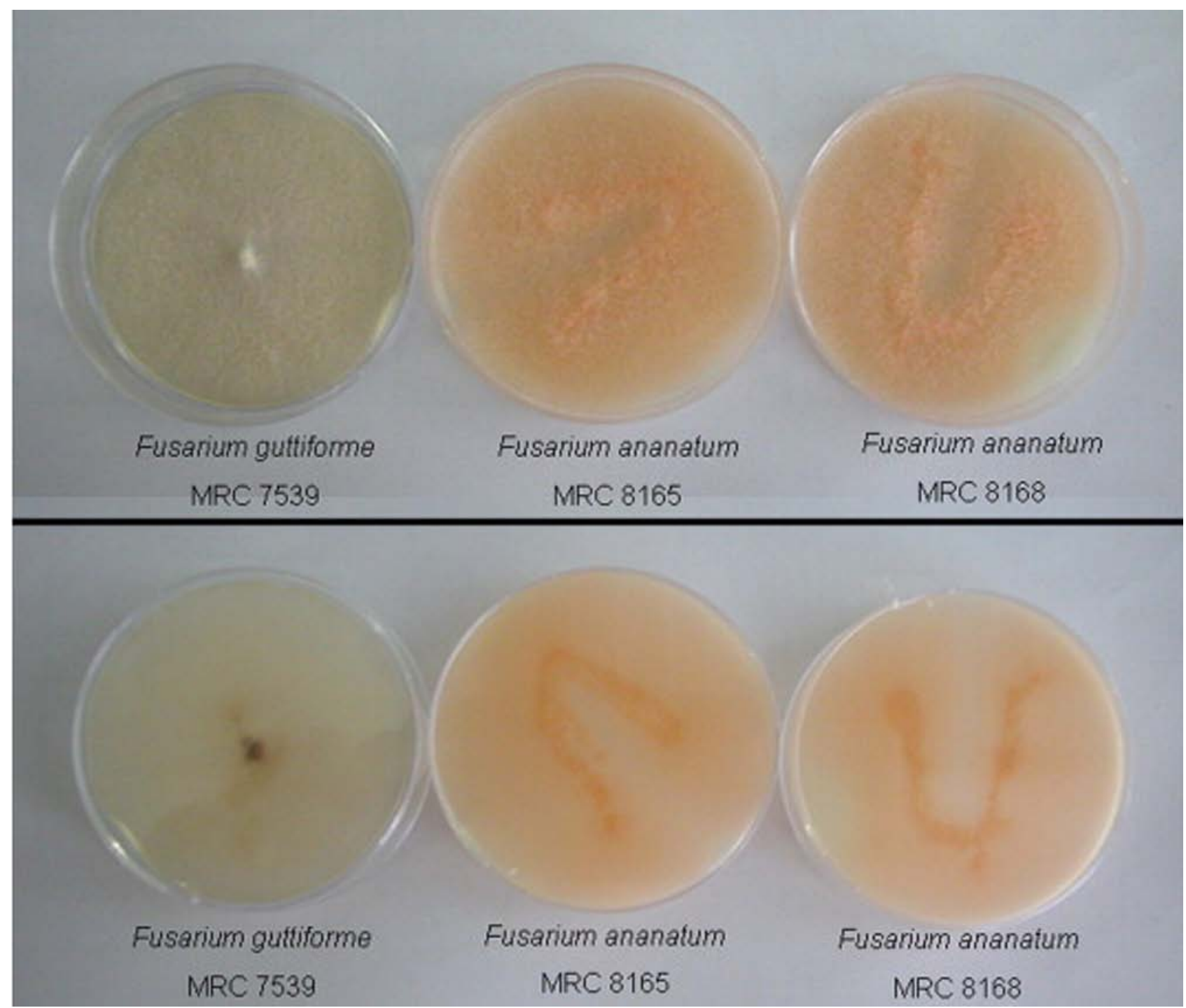

Fig 6. Colony morphology of Fusarium ananatum and F. guttiforme on PDA at $25{ }^{\circ} \mathrm{C}$ after $5 \mathrm{~d}$. First set of plates represent the top of the colonies and the second row of plates represent the reverse of the colonies.

\section{Mating studies and MAT genes}

No perithecia were observed in any of the crosses between or amongst the pineapple isolates from Brazil and South Africa. There were also no positive results for crosses between the South African pineapple isolates and the mating tester strains for eight of the biological species in G. fujikuroi species complex. The control crosses for all the tester strains produced fertile progeny showing that conditions for these tests were appropriate to stimulate sexual recombination. All of the seven South African isolates had the MAT-2 idiomorph and were thus of the same mating type. 


\section{Taxonomy}

The Fusarium isolates from pineapple in South Africa could easily be separated from those of $F$. guttiforme from pineapple in Brazil based on DNA sequence comparisons for three different gene regions. These isolates were also phylogenetically distinct from those of all other species in the $G$. fujikuroi species complex. The isolates from pineapple in South Africa could also be distinguished from F. guttiforme based on distinct morphological characteristics such as the nature of the conidiophores and the colony colour. This species is, therefore, described as a new taxon as follows.

Fusarium ananatum A. Jacobs, Marasas \& van Wyk, sp. nov. (Fig 7)

\section{MycoBank no.: MB 511686}

Etym.: The specific epithet refers to host, Ananas comosus, from which the species was isolated.

Margo coloniae integra. Coloniae crescunt circiter $3.2 \mathrm{~mm} / \mathrm{d}$ in $25^{\circ} \mathrm{C}$ in PDA. Mycelium aerium in medio coloniae congregatum; in PDA incrementum conformatione orbium concentricorum signatum. Mycelium aerium in PDA croceum, infra bubalinum. Sclerotia, sporodochia chlamydosporaeque desunt. Hyphae in SNA (2-)3-5(-6) $\mu \mathrm{m}$ latae. Conidia in pseudocapitulis aggregata. Conidiophorae in mycelio aerio erectae e substrato orientes, ramosae vel non, centrum coloniae versus plurimae, $(15-) 22-40(-47) \times(1-) 2-3 \mu \mathrm{m}$. Conidiophorae sympodialiter ramosae, mono- et polyphialidibus instructae. Phialides mycelii aerii cylindricae, monophialidicae, 10-46($56) \times(1-) 2-3 \mu \mathrm{m}$, ramis $3-17(-22) \times(1-) 2-3 \mu \mathrm{m}$, et polyphialidicae aperturis conidiogenis $2-4$, $25-90(-115) \times 1-2(-4) \mu \mathrm{m}$. Microconidia plerumque non septata raro uniseptata, $(6-) 8-16(-17) \times$ 1-2 $\mu \mathrm{m}$. Macroconidia in mycelio aerio facta subfalcata vel fere recta, superficiebus dorsalibus ventralibusque subparallelis, parietibus tenuibus, $(14-) 16-31(-32) \times 3-6 \mu \mathrm{m}$.

Colony margin entire. Colonies on PDA with average growth rate of $3.2 \mathrm{~mm} / \mathrm{d}$ at $25{ }^{\circ} \mathrm{C}$. Aerial mycelium concentrated at the middle of the colony and growth on PDA characterised by the formation of concentric circles. Aerial mycelium on PDA saffron (7f) in colour, reverse of colony buff (19"f) in colour. Sclerotia, sporodochia and chlamydospores absent. Hyphae on SNA (2-)3-5(6) $\mu \mathrm{m}$ wide. Conidia accumulating in false heads. Conidiophores on aerial mycelium originating erect from substrate, branched or unbranched, numerous towards centre of colony, (15-)22-40(-47) $\times(1-) 2-3 \mu \mathrm{m}$. Conidiophores sympodially branched bearing mono- and polyphialides. Phialides of the aerial mycelium, cylindrical, monophialidic, 10-46(-56) $\times(1-) 2-3 \mu \mathrm{m}$, with branches 3-17($22) \times(1-) 2-3 \mu \mathrm{m}$, and polyphialidic, with $2-4$ condiogenous openings, $25-90(-115) \times 1-2(-4) \mu \mathrm{m}$. Microconidia mostly 0 -septate with 1 -septate conidia occurring less abundantly, $(6-) 8-16(-17) \times 1-$ $2 \mu \mathrm{m}$. Macroconidia produced only on aerial mycelium and not in sporodochia, slightly sickleshaped to almost straight, with the dorsal and ventral surfaces almost parallel with thin walls, 3-4 septate, $(14-) 16-31(-32) \times 3-6 \mu \mathrm{m}$.

Materials examined: South Africa, Hluhluwe, Kwazulu Natal, A. comosus, November 2001, P.S. van Wyk, PREM 58713 (holotype; dried down culture of MRC 8165, FCC 2986, CMW 18685, CBS 118516). PREM 58714 (paratype; dried down culture of MRC 8166, FCC 2988, CMW 18686, CBS 118517); PREM 58715 (paratype dried down culture of MRC 8167, FCC 2990, CMW 18687, CBS 118518); PREM 58716 (paratype dried down culture of MRC 8168, FCC 2991, CMW 18688, CBS 118519). 


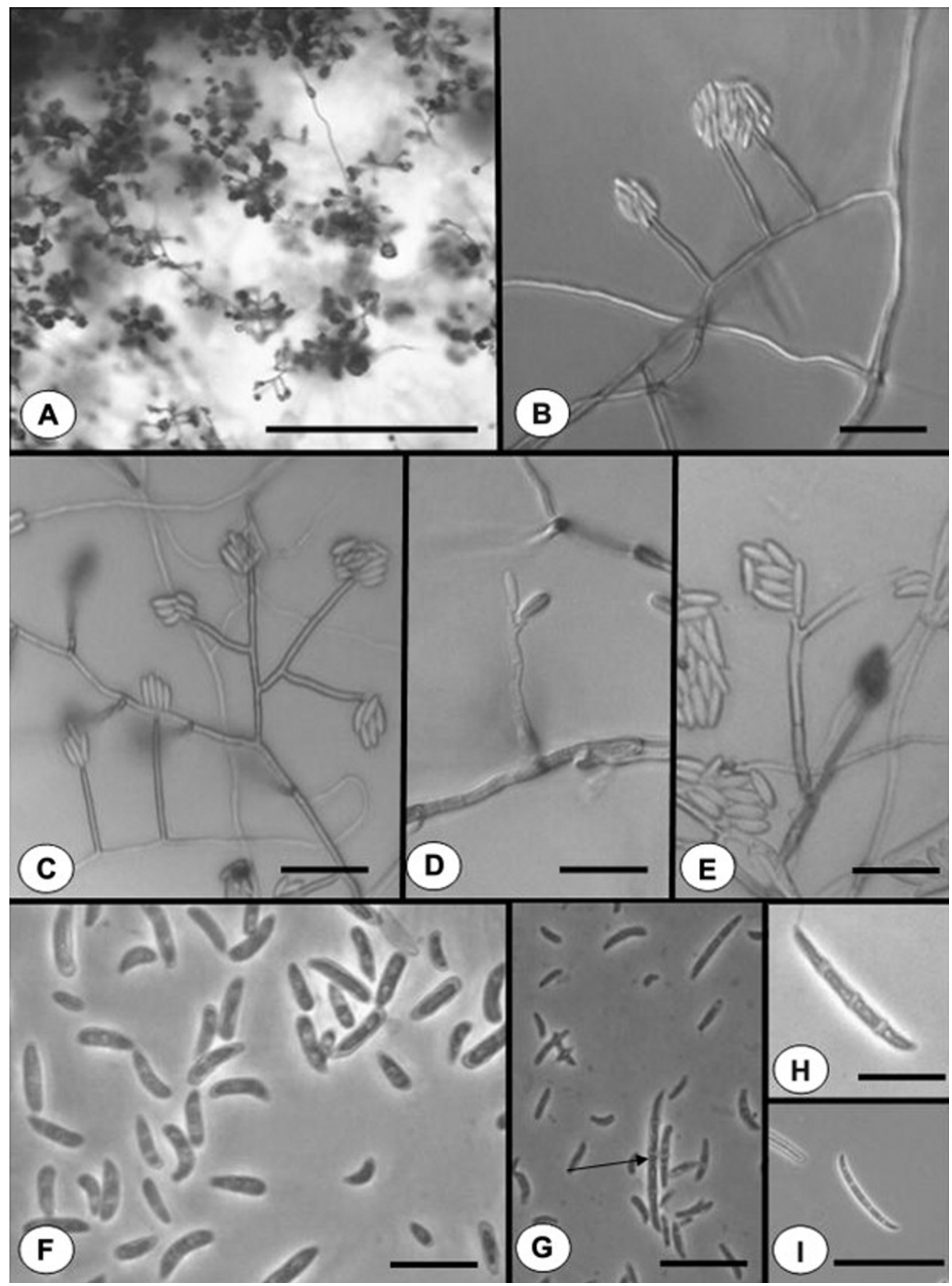

Fig 7. Morphological characteristics of Fusarium ananatum. (A) Erect conidiophores on aerial mycelium on SNA. (B) False conidial heads on SNA. (C) Branched and unbranched monophialides on CLA. (D) Polyphialdes on SNA. (E) Polyphialides on CLA. (F) Microconidia on CLA. (G-I) Macroconidia on CLA. Bars $(A)=130 \mu \mathrm{m} ;(B, C, E-H)=15 \mu \mathrm{m} ;(D)=30 \mu \mathrm{m}$; (I) $=20 \mu \mathrm{m}$. 


\section{Discussion}

Results of this study have shown that Fusarium isolates from diseased pineapple in South Africa represent a new species described here as $F$. ananatum. This species forms part of the G. fujikuroi species complex and can be distinguished from all other species in this group based on DNA sequence comparisons and morphology. Fusarium ananatum isolates were supported as monophyletic with high bootstrap support for all three gene phylogenies studied. By contrast, similar results were not observed for $F$. guttiforme.

Although DNA sequence comparisons form the most important basis for distinguishing $F$. ananatum from other related species, it is possible to distinguish the South African fungus based on morphology. The defining morphological characteristics include the nature of the conidiophores on the aerial mycelium and the distribution of the aerial mycelium on the surface of isolates. The original description of the F. guttiforme suggested that this species is characterised by erect and prostrate conidiophores (Nirenberg \& O'Donnell 1998). After the re-evaluation of the ex-type material (MRC 7539) and the Brazilian isolates, we conclude that F. guttiforme has distinctly prostrate conidiophores. This is in contrast to $F$. ananatum that is characterised by erect conidiophores on the aerial mycelium. The colony morphology of these two groups on SNA is also distinct. F. ananatum is characterised by concentrations of aerial mycelium at the centres of plates. In contrast, $F$. guttiforme has aerial mycelium distributed evenly over the surface of the colonies. Concentric circles of mycelial growth were also observed in $F$. ananatum cultures while these are absent in F. guttiforme. Furthermore, the distinct saffron colony colour of $F$. ananatum on PDA distinguishes it from $F$. guttiforme, which has dark purple coloured colonies on PDA.

Despite numerous attempts to cross isolates, no perithecia were obtained between the tester strains for eight mating populations in the G. fujikuroi species complex (Desjardins 2003) and the South African isolates from pineapple. Crosses amongst isolates of $F$. ananatum also failed to produce perithecia. This clearly resulted from the fact that the seven isolates tested all had the same mating type idiomorph. It is thus possible that crosses amongst a larger number of isolates, assuming some have the MAT-1 idiomorph, might produce a teleomorph.

Symptoms associated with both $F$. guttiforme and $F$. ananatum on fruit are similar but they are less severe in the case of the latter fungus. For F. guttiforme, these symptoms include a light to dark brown discolouration of the fruitlet septa that can extend to the fruitlet core (Rohrbach 1994). The infected fruit area initially appears off-colour, then becomes sunken with profuse pink sporulation and exudation of gum (Rohrbach 1994). Similar core discolouration occurs in fruit infected with $F$. ananatum. However, the infected fruit area is characterised by a V-shaped lesion that initially appears discoloured, and then becomes sunken. No exudation of gum was observed in the case of pineapples infected with $F$. ananatum, which appears to be a symptom typical of fusariosis.

In their re-evaluation of the Gibberella fujikuroi species complex, O'Donnell et al. (1998) included an isolate from $A$. comosus in England (NRRL $22945=$ CBS $184.29=$ IMI $375350=$ DAOM 225144) as F. guttiforme. In the present study, this isolate grouped in the clade that accommodates the $F$. ananatum isolates (Fig 2; Fig 3; Fig 4). It is also the only isolate included in the morphological comparison by Nirenberg \& O'Donnell (1998) that originates from the United Kingdom and not a South American country. This unusual grouping is further supported by the fact that South Africa exports pineapples to the United Kingdom and, thus, may have inadvertently sent fruit infected with $F$. ananatum to that country. This emphasises the importance of basing phylogenetic relationships employing ex-type strains and not on other isolates that might not represent the fungus intended for comparison. 
At present, nothing is known regarding the pathogenicity of $F$. ananatum. The fungus is closely associated with rot of fruit and it most likely is the cause of this disease. However, pathogenicity tests will be needed to determine its relative importance as a pathogen.

\section{Acknowledgments}

We thank the members of the Tree Protection Co-operative Programme (TPCP), the National Research Foundation (NRF) and the THRIP initiative of the Department of Trade and Industry (DTI), South Africa for financial support.

\section{Literature Cited}

Aoki T, O’Donnell K, Ichikawa K, 2001. Fusarium fractiflexum sp. nov. and two other species within the Gibberella fujikuroi species complex recently discovered in Japan that form aerial conidia in false heads. Mycoscience 42: 461-478.

Borras O, Santos R, Matos AP, Cabral RS, Arzola M, 2001. A first attempt to use a Fusarium subglutinans culture filtrate for the selection of pineapple cultivars resistant to fusariose disease. Plant Breeding 120: 435-438.

Carbone I, Kohn LM, 1999. A method for designing primer sets for speciation studies in filamentous ascomycetes. Mycologia 91: 553-556.

Correll JC, Klittich CJR, Leslie JF, 1987. Nitrate nonutilizing mutants of Fusarium oxysporum and their use in vegetative compatibility tests. Phytopathology 77: 1640-1646.

Desjardins AE, 2003. Gibberella from A(venaceae) to Z(eae). Annual Review of Phytopathology 41: $177 \mathrm{e} 198$.

Edmonstone-Sammons C, 1958. Some aspects of black spot in pineapples. South African Journal of Agricultural Science 1: 111-120.

Farris JS, Kallersj M, Kluge AG, Bult C, 1994. Testing significance of congruence. Cladistics 10: 315-320.

Glass NL, Donaldson GC, 1995. Development of primer sets designed for use with the PCR to amplify conserved genes from filamentous ascomycetes. Applied and Environmental Microbiology 61: 1323-1330.

Hillis DM, Huelsenbeck JP, 1992. Signal, noise, and reliability in molecular phylogenetic analyses. Journal of Heredity 83: 189-195.

Hildalgo OB, Santos R, Tussel RT, Pires de Matos A, Cabrl RS, Avzola M, Perez MC, 1999. Phytotoxicity of Fusarium subglutinans culture filtrates in vitro plantlets and calli of resistant and susceptible pineapple (Ananas comosus). Plant Pathology 48: 756-758.

Huelsenbeck JP, Ronquist F, 2001. MRBAYES: Bayesian inference of phylogeny. Bioinformatics 17: 754-755.

Nelson PE, Tousson TA, Marasas WFO, 1983. Fusarium Species: an Illustrated Manual for Identification. University Park, Pennsylvania State University Press. 
Nirenberg HI, 1976. Untersuchungen über die morphologische und biologische Differenzierung in der Fusarium-Sektion Liseola. Mitteilungen aus der Biologischen Bundesanstalt für Landund Forstwirtschaft 169: 1-117.

Nirenberg HI, O’Donnell K, 1998. New Fusarium species and combinations within the Giberella fujikuroi species complex. Mycologia 90: 434-458.

O’Donnell K, Cigelnik E, Nirenberg HL, 1998. Molecular systematics and phylogeography of the Gibberella fujikuroi species complex. Mycologia 90: 465-493.

O’Donnell K, Nirenberg HI, Aoki T, Cigelnik E, 2000. A multigene phylogeny of the Gibberella fujikuroi species complex: detection of additional phylogenetically distinct species. Mycoscience 41:61-78.

Pires de Matos A, 1995. Pathological aspects of the pineapple crop with emphasis on the fusariosis. Revista de la Facultad de Agrarias (Maracay) 21: 179-197.

Ploetz RC, 2001. Significant diseases in the tropics that are caused by species of Fusarium. In: Summerell BA, Leslie JF, Backhouse D, Bryden WL, Burgess LW (eds), Fusarium: Paul Nelson Memorial Symposium. The American Phytopathological Society Press, St Paul, pp. 295309.

Raeder U, Broda P, 1985. Rapid preparation of DNA from filamentous fungi. Letters in Applied Microbiology 1: 17-20.

Rayner RW, 1970. A Mycological Colour Chart. Commonwealth Mycological Institute/British Mycological Society, London.

Rohrbach KG, Pfeiffer JB, 1976. Susceptibility of pineapple cultivars to fruit diseases incited by Penicillium funiculosum and Fusarium moniliforme. Phytopathology 66: 1386-1390.

Rohrbach KG, 1994. Fusariosis. In: Ploetz RC, Zentmeyer GA, Nishijima WT, Rohrbach KG, Ohr HD (eds), Compendium of Tropical Diseases. The American Phytopathological Society Press, St. Paul, pp. 45-56.

Rohrbach KG, Schmitt D, 2003. Diseases of pineapple. In: Ploetz RC (ed), Diseases of Tropical Fruit Crops. CABI Publishing, Oxford, pp. 443-464.

Steenkamp ET, Wingfield BD, Coutinho TA, Wingfield MJ, Marasas WFO, 1999. Differentiation of Fusarium subglutinans f. sp. pini by histone gene sequence data. Applied and Environmental Microbiology 65: 3401-3406.

Steenkamp ET, Wingfield BD, Coutinho TA, Zeller KA, Wingfield MJ, Marasas WFO, Leslie JF, 2000. PCR-based identification of MAT-1 and MAT-2 in the Gibberella fujikuroi species complex. Applied and Environmental Microbiology 66: 4378-4382.

Swofford DL, 2002. PAUP*: phylogenetic Analysis Using Parsimony (*and Other Methods) Version 4. Sinauer Associates, Sunderland, MA.

Ventura JA, Zambolim L, Chaves GM, 1993a. Integrated management system for pineapple Fusarium disease control. Acta Horticulturae 334: 439-453. 
Ventura JA, Zambolim L, Gilbertson L, 1993b. Proposic,a a de nova forma specialis em Fusarium subglutinans no abacaxizeiro. Fitopatologia Brasileira Supplemento 18: 280. 